\title{
Conflict Management Strategies among Principals in Government Technical Colleges in Rivers State
}

\author{
Deebom, Mtormabari Tambari ${ }^{1}$, Buapu, Hopeson Asime ${ }^{2}$ \\ Department of Technical/Vocational Education, Rivers State University of Science and Technology, Port Harcourt
}

\begin{abstract}
This study examines conflict management strategies among principals in Government Technical Colleges in Rivers State using a descriptive design. A sample of 120 respondents (40 administrative staff and 80 teachers) was selected through simple random sampling technique. Three research questions were answered while two hypotheses were tested at 0.05 level of significance. The instrument used for data collection was a structured questionnaire which was validated by two principals. A reliability coefficient of 0.80 of the instrument was established through Cronbach Alpha. It was found that avoiding, compromising, collaborating, mediation, dialogue and others are conflict management strategies adopted by principals of Government Technical Colleges in Rivers State. Based on the findings, it was recommended among others that principals should see conflict as being inevitable in their daily administrative activities, principals should adopt any strategy that can help in reducing conflict such as democratic principles and open treatment to others etc.
\end{abstract}

Keywords: Conflict, Management, Leadership Styles, Strategies

\section{Introduction}

Most social organizations such as political groups, social clubs and educational establishments are complex organizations. They are made up of people with different backgrounds in terms of needs, goals, skills, values, status, knowledge, behavior, perception, culture, religion, ethnicity and others. Under such state of diversity, individuals and groups are sometimes bound to disagree on issues with emotional intensity and conflict may occur. Based on this, Obi (2004) perceived conflict as human and social problems which involve mutual hostility, differences, disagreements, opposition resulting to man's inhumanity to man, use of violence, and turning point or crisis, which can escalate to the level of psychological warfare, physical or naked war. According to Chaturvedi (2006), conflict is described as an opposition or competition between two or more forces arising either from the pursuit of incompatible goals or a class of rival opinions. Conflict have become one of the major problems identified by many Nigerians today and have become one of the most prevalent issues in organizations such as civil, social, religious, political and even families. This has transcended into educational institutions especially in Government Technical Colleges which hampered academic activities.

For Ulo (2011), conflict is a controversy or divergence of opinion between two or more people in an organisation about something that was not done or to be done in a work environment in which opposing views are strongly held. Conflict could be described as a tension state which attempts to prevent or frustrate another person from achieving a desired goal. In another contribution, Omoike (2014) defined conflict as that which could happen between two or more people or groups with incompatible goals in an organization while Ogonor (2004) views conflict as the process where a party deliberately makes an effort to block the efforts of another party (person) and thereby frustrates the latter in attempt to attain goals or further interest.

Infer from the above, it connotes that conflicts are deliberate attempts of human beings to frustrate the efforts of an individual, group, state or nation. Ogonor (2013) aptly concluded that conflicts are caused by internal and external factors which may have their origin and root from management policy and style. These policies may include differences in subordinate and super ordinate attitude, perception, politics, immature behaviour by management staff and employee, undue concentration of power, administrator's style, nepotism and inappropriate management of organizational resources.

In this paper, conflict is seen as an unusual situation in which the desirable relationship for working towards definite desirable and achievable goals or objectives no longer exists. It is also defined as a situation that has reached an extremely difficult or dangerous point; a time of great disagreement, uncertainty or suffering. Due to the inevitability nature of conflict in all organizations and educational institutions; school principals, proprietors, managers and administrators must learn to manage conflict rather than attempt to thwart or eliminate it (Peretomode, 1997). The effective administration of Government Technical Colleges (GTC) system in Rivers State to a large extent depends on a cordial and cooperate working relationship among principals, teachers, proprietors, and students. According to Abanyam (2001), the harmonious working relationship, mutual implementation of decisions and peaceful academic environment will be jeopardized, if the school and members of the school community are often in conflict; hence conflict management becomes inevitable in Government Technical Colleges.

Conflict management according to Behfar, Peterson, Mannis and Trochion (2008) is a process by which organizations deal with a major events or events that threatens the organisation, its stakeholders and the general public. Aja (2015) opined that Conflict management is a crucial issue in school administration because no meaningful teaching and learning can take place in a conflict ridden environment. Aja (2015) further stressed that in considering the fact that where two or more people are together, there is bound to be

Volume 6 Issue 1, January 2017

www.ijsr.net

Licensed Under Creative Commons Attribution CC BY 


\section{International Journal of Science and Research (IJSR) \\ ISSN (Online): 2319-7064}

Index Copernicus Value (2015): 78.96 | Impact Factor (2015): 6.391

disagreement which when left unattended could result to conflict. Some school administrators view conflict as a negative situation which must be avoided at all cost but in reality conflict necessitates management because it creates opportunity for personal growth especially when proper strategy is advanced for solving the conflict. Principals as the administrative heads of secondary schools are faced with conflicts in the bid to influence and co-ordinate school resources for goal attainment.

Benson (2011) noted that school principals are faced with conflicts emanating from their administrative style, policy implementation, supervision of instruction, examination malpractice, illegal levies, staff posting and transfer, ParentTeachers Association (PTA) and other school based committees as well as school related issues. It is therefore necessary that school managers or administrators should be knowledgeable in the conflict management strategies. This gives rise to different strategies and styles or techniques principals, administrators, policy makers of Government technical College adopt in managing conflicts. Authorities in dispute and conflict management have identified the following styles of conflict management used by leaders in various organizations. They include: accommodation, compromise, collaboration, competition, withdrawal or avoidance (Ohio Commission on dispute and conflict management report cited in Nwofia (2015). Also, Cross (1999) and Demer (2002), identified arbitration, mediation, negotiation, reconciliation bargaining, problem solving and peace-making through the use of force as some of the strategies for conflict management in the organisation. Other student's crises management strategies as identified by Jones and Melcher (1982) include the use of joint problem solving, use of force, third party conference, persuasion, confrontation, win-lose and avoidance. The researchers defined conflict management as strategies adopted by principals to reduce or resolve existing crisis and to prevent the occurrence of subsequent ones in any organizations.

\section{Statement of the Problem}

In every educational institutions in Nigeria, conflict exist among students as their attendant problems are now real and as such Government Technical Colleges in Rivers State are now experiencing conflict in one form or the other. Such conflict is either between principals and teachers or students and school authority. When conflicts arise, they result to lawlessness, outbreak of violence, death, loss of properties and equipment, closure of schools and so on. Also, a lot of resources both human and material are destroyed and usually after the conflict, such schools come back worse-off than they had been in terms of administrative staff and facilities available. When these happens, school academic calendar are altered which affects the students' academic achievement and performance; hence the aims and goals of establishing GTC are ultimately defeated.

Although, some measures are being taken to control conflict by school administrators but conflict still exists in Government Technical Colleges in Rivers State. It is not precisely known why conflict still resists the method being adopted and the level of effectiveness of these methods as perceived by principals in resolving the problem. Since managers or school administrators must live with school conflict both interpersonal and inter-group, the best attitude for effective and efficient execution should have towards conflict is to recognize its inevitability in the workplace and develop an understanding ways of managing, minimizing and resolving conflict. Otherwise, an uncontrolled conflict may lead to organizational chaos. The factors inhibiting permanent solution to these are issues yet to be resolved. The problem being addressed by this paper is conflict management strategies adopted by principals of Government Technical Colleges in Rivers State in dealing with the conflict situations.

\section{Purpose of the Study}

The main purpose of this paper is to examine the conflict management strategies adopted by principals of Government Technical Colleges in Rivers State. Objectively, the study tends to:

1) Identify the principals' leadership styles that cause conflict in Rivers State Government Colleges.

2) Examine if inadequate funding causes conflict in Rivers State Government Colleges.

3) Identify strategies adopted by principals of Government Technical Colleges in Rivers State to reduce conflict.

\section{Research Questions}

1) What are the principals' leadership styles that cause conflict in Government Technical Colleges in Rivers State?

2) How does inadequate funding cause conflict in Rivers State Government Technical Colleges?

3) What are the strategies adopted by principals' of Government Technical Colleges in Rivers State in reducing conflict?

\section{Hypotheses}

The following null hypotheses were formulated and tested at 0.05 level of significance.

$\mathbf{H O}_{1}$ : There is no significant difference in the mean score of administrative staff and teachers on the principals' leadership styles that cause conflict in Government Technical Colleges in Rivers State.

$\mathbf{H O}_{2}$ : There is no significant difference in the mean score of administrative staff and teachers on the strategies adopted by principals' of Government Technical Colleges in Rivers State in reducing conflict.

\section{Methodology}

The study was a descriptive survey that sought the opinion of administrative staff and teachers on conflict management strategies adopted by principals of Government Technical Colleges in Rivers State which includes Government Technical College Port Harcourt, Government Technical College Ahoada, Government Technical College Tombia and Government Technical College Eleogu. The population of the study comprised all administrative staff (Principals, Vice-Principals and Heads of Units) and teachers from the four Government Technical Colleges in Rivers State. The sample for the study was 10 administrative staff and 20 teachers selected through simple random sampling technique from each schools totaling to 120 (40 administrative staff 


\section{International Journal of Science and Research (IJSR) \\ ISSN (Online): 2319-7064}

Index Copernicus Value (2015): 78.96 | Impact Factor (2015): 6.391

and 80 teachers) respondents. The instrument for data collection was a 21-item closed structured questionnaire title "Technical College Principals' Strategies in Conflict Management (TCPSCM)" with two sections: A and B. Section A was designed to captures the respondents bio-data while section B provides responses to answer research question 1, 2 and 3 which was patterned after Likert 5-point rating scale of Strongly Agree, Agree, Undecided, Disagree and Strongly Disagree with numerical values of 5, 4, 3, 2 and 1 respectively. Data collected were analysed using mean with standard deviation through Statistical Package for Social Sciences (SPSS) with an acceptable minimum mean value of 3.00. The instrument was subjected to face and content validity by two principals of Government Technical College in Rivers State. The reliability of the instrument was determined through Cronbach Alpha and a reliability coefficient of 0.80 was established. Hypotheses were tested using the Z-test.

\section{Results and Discussion of Findings}

Research Question 1: What are the principals' leadership styles that cause conflict in Government Technical Colleges in Rivers State?

Table 1: Mean Response of Staff and Teachers on Principals' Leadership Styles that Causes Conflict in Government Technical Colleges in Rivers State $\left(\mathrm{N}_{1}=40\right.$; $\mathrm{N}_{2}=80$ ).

\begin{tabular}{|c|c|c|c|c|c|}
\hline \multirow{2}{*}{$\begin{array}{l}\text { S. } \\
\text { No }\end{array}$} & \multirow[t]{2}{*}{ Item Statement } & \multicolumn{2}{|c|}{$\begin{array}{c}\text { Administrative } \\
\text { Staff }\end{array}$} & \multicolumn{2}{|c|}{ Teachers } \\
\hline & & $\mathrm{X}_{1}$ & Decision & $\mathrm{X}_{2}$ & Decision \\
\hline \multicolumn{6}{|c|}{$\begin{array}{c}\text { Principal leadership style that causes } \\
\text { Conflict in Technical College }\end{array}$} \\
\hline 1 & $\begin{array}{l}\text { Principals' Autocratic } \\
\text { leadership style }\end{array}$ & 3.8 & Accepted & 3.95 & Accepted \\
\hline 2 & Principals' Democratic style & 2.36 & Rejected & 2.91 & Rejected \\
\hline 3 & Principals' laisser-faire style & 2.41 & Rejected & 2.53 & Rejected \\
\hline 4 & Principals' Dictatorship style & 3.8 & Accepted & 3.49 & Accepted \\
\hline 5 & $\begin{array}{l}\text { Principals' integrating follower } \\
\text { in Decision making }\end{array}$ & 2.91 & Rejected & 2.87 & Rejected \\
\hline & Grand Mean $\left(X_{\mathrm{G}}\right)$ & 3.06 & Accepted & 3.15 & Rejected \\
\hline
\end{tabular}

Source: Researchers' Field Survey:2016

The analysis of research question 1 shows a grand mean of 3.06 for administrative staff and 3.15 for teachers which implies that principal's leadership styles cause's conflict in Government Technical Colleges in Rivers State. Since the grand mean of 3.06 and 3.15 are higher than the standard reference mean of 3.00 for decision, it means that the statement is accepted.

Research Question 2: How does inadequate funding cause conflict in Rivers State Government Technical Colleges?

Table 2: Mean Response of Staff and Teachers on how Inadequate Funding Causes Conflict in Government Technical Colleges in Rivers State $\left(\mathrm{N}_{1}=40 ; \mathrm{N}_{2}=80\right)$

\begin{tabular}{|c|c|c|c|c|c|}
\hline \multirow{2}{*}{$\begin{array}{c}\text { S. } \\
\text { No. }\end{array}$} & \multicolumn{2}{|c|}{$\begin{array}{c}\text { Administrative } \\
\text { Item Statement }\end{array}$} & \multicolumn{2}{|c|}{ Teachers } \\
\cline { 3 - 6 } & $\mathrm{X}_{1}$ & Decision & $\mathrm{X}_{2}$ & Decision \\
\hline \multirow{2}{*}{6} & $\begin{array}{l}\text { Lack of funds for provision of } \\
\text { public utilities causes conflict } \\
\text { in schools. }\end{array}$ & 3.88 & Accepted & 3.6 & Accepted \\
\hline
\end{tabular}

\begin{tabular}{|c|l|l|l|l|l|}
\hline 7 & $\begin{array}{l}\text { Non availability of funds for } \\
\text { provision of hostel } \\
\text { accommodation causes } \\
\text { conflict in technical colleges }\end{array}$ & 3.54 & Accepted & 3.94 & Accepted \\
\hline 8 & $\begin{array}{l}\text { Non availability of funds for } \\
\text { procurement of consumables } \\
\text { like electrode, gas, electronics } \\
\text { components for practical } \\
\text { causes conflict in technical } \\
\text { colleges. }\end{array}$ & 3.76 & Accepted & 3.47 & Accepted \\
\hline 9 & $\begin{array}{l}\text { Non availability of funds for } \\
\text { provision of workshop } \\
\text { equipment causes conflict in } \\
\text { technical colleges. }\end{array}$ & 3.71 & Accepted & 3.44 & Accepted \\
\hline 10 & $\begin{array}{l}\text { Non availability of funds for } \\
\text { the provision of classroom, } \\
\text { staffroom causes conflict in } \\
\text { technical Colleges. }\end{array}$ & 3.83 & Accepted & 3.7 & Accepted \\
\hline & Grand Mean $\mathrm{X}_{\mathrm{G}}$ ) & 3.74 & Accepted & 3.63 & Accepted \\
\hline
\end{tabular}

Source: Researchers' Field Survey:2016

The analysis of research question 2 shows a grand mean of 3.74 for administrative staff and 3.63 for teachers which implies that inadequate funding cause's conflict in Government Technical Colleges in Rivers State. Since the grand mean of 3.74 and 3.63 are higher than the standard reference mean of 3.00 for decision, it means that the statement is accepted.

Research Question 3: What are the strategies adopted by principals' of Government Technical Colleges in Rivers State in reducing conflict?

Table 3: Mean Response of Staff and Teachers on Strategies Adopted by Principals of Government Technical Colleges in Rivers State $\left(\mathrm{N}_{1}=40 ; \mathrm{N}_{2}=80\right)$.

\begin{tabular}{|c|c|c|c|c|c|}
\hline & & \multicolumn{2}{|c|}{$\begin{array}{c}\text { Administrative } \\
\text { Staff }\end{array}$} & \multicolumn{2}{|c|}{ Teachers } \\
\cline { 3 - 6 } S. & Item Statement & $\mathrm{X}_{1}$ & Decision & $\mathrm{X}_{2}$ & Decision \\
\hline
\end{tabular}

The following are conflict

management Strategies used by principals of Technical Colleges in Rivers State.

\begin{tabular}{|c|l|c|l|c|l|}
\hline 11 & $\begin{array}{l}\text { Authoritative command } \\
\text { strategy }\end{array}$ & 3.76 & Accepted & 3.45 & Accepted \\
\hline 12 & $\begin{array}{l}\text { The use of majority rule } \\
\text { strategy }\end{array}$ & 3.64 & Accepted & 3.52 & Accepted \\
\hline 13 & $\begin{array}{l}\text { The use of arbitration } \\
\text { strategy }\end{array}$ & 3.57 & Accepted & 3.94 & Accepted \\
\hline \multirow{2}{*}{14} & $\begin{array}{l}\text { Principals adopt resort to } \\
\text { rule strategy }\end{array}$ & 3.67 & Accepted & 3.6 & Accepted \\
\hline & $\begin{array}{l}\text { Principals adopt changing } \\
\text { the individuals involved } \\
15\end{array}$ & & & & \\
\hline 16 & Strategy to resolved conflict. & 3.61 & Accepted & 3.9 & Accepted \\
\hline 17 & $\begin{array}{l}\text { The use of mediation } \\
\text { between parties }\end{array}$ & 3.62 & Accepted & 3.43 & Accepted \\
\hline 18 & Accomodating & 3.08 & Accepted & 3.21 & Accepted \\
\hline 19 & Collaborating & 3.59 & Accepted & 3.92 & Accepted \\
\hline 20 & Compromising & 3.7 & Accepted & 3.61 & Accepted \\
\hline 21 & Avoiding & 3.38 & Accepted & 3.4 & Accepted \\
\hline & Grand Mean $\left(\mathrm{X}_{\mathrm{G}}\right)$ & 3.6 & Accepted & 3.4 & Accepted \\
\hline
\end{tabular}

Source: Researchers' Field Survey:2016

\section{Volume 6 Issue 1, January 2017




\section{International Journal of Science and Research (IJSR) \\ ISSN (Online): 2319-7064}

Index Copernicus Value (2015): 78.96 | Impact Factor (2015): 6.391

The analysis of research question 3 shows a grand mean of 3.84 for administrative staff and 3.58 for teachers which implies that principal's of Government Technical Colleges in Rivers State adopted the listed methods as strategies for managing conflict in their various schools. Since the grand mean of 3.84 and 3.58 are higher than the standard reference mean of 3.00 for decision, it means that the statement is accepted.

\section{Test of Hypotheses}

$\mathbf{H O}_{1}$ : There is no significant difference in the mean score of administrative staff and teachers on the principals' leadership styles that cause conflict in Government Technical Colleges in Rivers State.

Table 4: Z-test analysis of administrative staff and teachers on principals' leadership styles that causes conflict in technical colleges in Rivers State

\begin{tabular}{|c|c|c|c|c|c|c|c|c|}
\hline Group & $N$ & $X$ & $S D$ & $\alpha$ & $D f$ & Zcrit & Zcal & Decision \\
\hline Staff & 40 & 3.06 & 0.87 & \multirow{2}{*}{0.05} & 178 & 1.96 & -0.70 & Accepted \\
\cline { 1 - 6 } Teachers & 80 & 3.15 & 0.74 & & & & & \\
\hline
\end{tabular}

The null hypothesis is accepted since the Zcal (-0.70) is less than the Zcrit (1.960). The negative sign (-) with the Zcal value is ignored. This implies that there is no significant difference in the mean opinion of the respondents on principal's leadership styles that causes conflict in Government Technical Colleges in Rivers State.

$\mathbf{H O}_{2}$ : There is no significant difference in the mean score of administrative staff and teachers on the strategies adopted by principals' of Government Technical Colleges in Rivers State in reducing conflict.

Table 5: Z-test analysis of administrative staff and teachers on strategies adopted by principals of technical colleges in Rivers State in reducing conflict

\begin{tabular}{|c|c|c|c|c|c|c|c|c|}
\hline Group & $N$ & $X$ & $S D$ & $\alpha$ & $D f$ & Zcrit & Zcal & Decision \\
\hline Staff & 40 & 4.37 & 0.84 & \multirow{2}{*}{0.05} & 178 & 1.96 & -0.77 & Accepted \\
\hline Teachers & 80 & 4.47 & 0.73 & & & & & \\
\hline
\end{tabular}

The null hypothesis is accepted since the Zcal (-0.77) is less than the Zcrit (1.960). The negative sign (-) with the Zcal value is ignored. This implies that there is no significant difference in the mean opinion of the respondents on strategies adopted by principals of Government Technical Colleges in Rivers State in reducing conflict.

\section{Discussion of Findings}

Table 2 revealed that lack of provision for accommodation, staffroom, procurement of consumables like electrode, gas for practical are some of the causes of conflict due to inadequate funds. This result is in collaboration with Republic of Kenya (2001) where it was reported that unavailability of basic facilities including staffroom and teaching (practical) materials results to student's unrest while some head teachers lack even offices to transact official duties leading to conflicts with other administrators and students.
Table 3 shows that principals of Government Technical Colleges in Rivers State adopted the listed item statements such as authoritative command, majority rule, the use of dialogue, mediation through third parties as strategies in managing conflicts in technical colleges in Rivers State. This finding tallied with the submission of Dzurgba (2006) who opined that conflicts could be settled through dialogue and also could be persuaded to peace without further problems.

The finding is also in agreement with Miller (2003) who saw mediation as the intervention of a third party. The objective is to help parties in a conflict within an environment of controlled communities to reach solution to their problems. The result is in collaboration with the assertion of Umstot as cited in Oboegbulem and Alfa (2013) who listed four strategies that could be used to manage or resolve conflicts as: "avoiding, accommodating, compromising, and collaborating". Umstot further contended that when choosing a Conflict Resolution Strategies (CRS), the first decision is whether to confront or avoid the conflict or not. Also, this result shows that most principals of Government Technical College in Rivers State adopted the authoritative command as a strategy in managing conflict in schools.

\section{Conclusion and Recommendation}

The main purpose of this study is to examine the conflict management strategies principals adopt in Government Technical Colleges in Rivers State. It is worthy to mention that there is no universal conflict management strategies but the strategy or strategies to adopt is dependent on the present situation and the causes of the conflict. Therefore, it is the duty of the principal to be conversant with as many conflict management strategies as possible so that its application could be appropriate in any given conflict situation. This will go a long way in achieving the desired conducive school atmosphere that will guarantee effective administration of Government Technical Colleges in Rivers State.

Based on the findings of this study, the following were recommended:

- Adequate funding should be release into Government Technical Colleges to provide consumable material, provision of staffrooms, teaching and practical materials in order to avoid conflict of any magnitude.

- Principals should engage themselves in intensive motivational techniques, open door administration, and participatory governance to drastically reduce conflict in schools.

- Principals should see conflict as being inevitable in their daily administrative activities.

- Principals should adopt any strategy that can help in reducing conflict such as democratic principle and open treatment to others.

\section{References}

[1] Abanyam, P. S. (2001). Principal teacher conflict: As a source of dysfunctional secondary school administration in Benue State. Unpublished doctoral dissertation, University of Calabar. 


\section{International Journal of Science and Research (IJSR) \\ ISSN (Online): 2319-7064 \\ Index Copernicus Value (2015): 78.96 | Impact Factor (2015): 6.391}

[2] Aja, S. N. (2015). Conflict management approaches principals adopt for effective administration of secondary schools in ebonyi state, International Journal of Science and Research, 4(12), 2009-2013.

[3] Behfar, K. J., Peterson, R. S., Mannis, E. A. \& Trochion, W.M.K. (2008). The critical role of conflict resolution in terms: A close look at the links between conflict type, conflict management strategies and team outcomes. Journal of Applied Psychology 9 (3), 170188.

[4] Benson, I.D. (2011). Causes of conflicts in our secondary schools and related unrest. Jos: Marx and Coy. Inc.

[5] Chaturvedi, A. K. (2006). Academic dictionary of political science. New Delhi: Academic Publishers.

[6] Cross, S. (1999). The Models of conflict resolution: Effect on inter-group expectancy and attitudes. New York: Fall Publishing House.

[7] Demer, J. (2002). Settling international dispute retrieved from: http://www.eia.doc.gov/emen.

[8] Dzurgba, A. (2006). Prevention and management of conflict. Kogi, New Bodija, Ibadan: London Books Publishers.

[9] Jones, R. F., \& Melcher, B. H. (1982). Personality and the preference for models of conflict resolution. Human Relations, 8(3), 469-658.

[10] Miller, C. A. (2003). A glossary of terms and concepts in peace and conflict studies. General: University for Peace.

[11]Nwofia, B. N. (2015). Conflict manifestations and management in secondary school in Ebonyi State, Nigeria. Unpublished PhD thesis proposal. Ebonyi State University, Abakaliki.

[12] Obi, E. (2004). Issues in educational administration. Enugu: Empathy International.

[13] Oboegbulem, A. \& Alfa, I. A. (2013). conflict resolution strategies in non-government secondary schools in Benue State, Nigeria. US-China Education Review B, 3(2), 91-102.

[14] Ogonor, B.O. (2004). Conflict management and resolution in organizations. In N.A. Nwogwu, M.E. Ijeoma and C.C. Nwagwu (eds). Organization and administration of education: Perspectives and Practices. Benin: Festa Printing Press Ltd. 249-265.

[15] Ogonor, B.O. (2013). Educational reformation for national security. A Conference Lead Paper Presented at the Institute of Education Abraka $11-15^{\text {th }}$ June, 2013.

[16] Omoike, D. (2014). Educational Management. A skill building approach. Charles and Patrick Booksmith House Ltd.

[17] Peretomode, V. F. (1997). Conflict management in organizations, Ikeja: Obauroh \& Ogbinaka Publishers.

[18] Republic of Kenya (2001). Report of the task force on student discipline and unrest in secondary schools. Nairobi: Government Printer.

[19]Ulo, F.O. (2011). Element of management: A Book of Reading. Enugu: Rhyce Kerek Publishers.

Volume 6 Issue 1, January 2017 www.ijsr.net 